\title{
Separating the Effects of Low Temperature, Ripening, and Light on Loss of Scald Susceptibility in Apples before Harvest
}

\author{
Cynthia L. Barden and William J. Bramlage \\ Department of Plant and Soil Sciences, University of Massachusetts, Amherst, MA 01003
}

Additional index words. ethephon, Malus domestica

\begin{abstract}
Cortland' and 'Delicious' apples (Malus domestics Borkh.) were exposed to an increasing number of hours below $10 \mathrm{C}$ before sequential harvests in each of 3 years. In separate experiments, 'Cortland' apples were a) sprayed with ethephon to induce ripening at moderate temperatures and b) bagged in late August to produce ripening at low light intensities. Scald development was determined after 4 to 5 months of storage at $0 \mathrm{C}$. Significant negative relationships with scald development occurred for hours below 10C, harvest date, and ripening indexes at harvest; however, the regressions with percentage scald were stronger for hours below $10 \mathrm{C}$ than for either harvest date or ripening. When ethephon-induced ripening occurred in the absence of low temperature, scald development decreased only slightly. Bagging fruit significantly delayed the loss of scald susceptibility with increasing hours below 10C. We conclude that low temperature was most responsible for rapid, substantial loss of scald susceptibility, and that light and ripening were secondary factors in this loss, interacting with the effects of temperature. Chemical name used: (2-chloroethyl)phosphonic acid (ethephon).
\end{abstract}

Many factors influence susceptibility of apples to superficial scald development after storage, including cultivar, orchard locality, weather, harvest maturity, and storage conditions (Fidler, 1957; Merritt et al., 1961; Meigh and Filmer, 1969).

Merritt et al. (1961) found that after 'Stayman' apples were exposed to $150 \mathrm{~h}$ below 10C before harvest, scald development decreased greatly, and after $190 \mathrm{~h}$ below 10C, little or no scald developed. Two recent studies also showed decreased scald with increased hours below 10C (Blanpied et al., 1991; Bramlage and Barden, 1989). Morris (1964), however, found that accumulated hours below $12.8 \mathrm{C}$ combined with a maturity index correlated best with scald development.

Immature apples often scald more than those harvested at maturity (Padfield, 1955; Smock and Southwick, 1945). Smock (1961) found that a sharp break in susceptibility often occurred with later harvests, and Blanpied et al. (1991) found a marked decrease in scald after a starch index of at least 5.3 was reached in 'Starkrimson Delicious'.

Applying ethephon to apples preharvest stimulates ripening (Edgerton and Blanpied, 1970; Greene et al., 1974). Several studies have examined the effects of ethephon on scald development; however, results are mixed. With 'Cortland' apples, scald development increased after ethephon was applied at 0.3 or 1 g. liter $^{-1} 6$ days before harvest (Windus and Shutak, 1977). However, scald incidence was less on 'Delicious' apples treated with ethephon at $0.5 \mathrm{~g} \cdot \operatorname{liter}^{-1} 3$ weeks before harvest, $0.25 \mathrm{~g} \cdot \operatorname{liter}^{-1} 4$ weeks before harvest, or 0.5 to $1.0 \mathrm{~g} \cdot \operatorname{liter}^{-1} 3$ months before harvest (Greene et al., 1977; Hammett, 1976).

Shutak and Kitchin ( 1966) studied the effects of light on scald by enclosing 'Cortland' and 'Grimes Golden' apples in white or black muslin bags in mid-August. Bagged apples scalded more than fruit not enclosed in bags, with those in black bags scalding

Received for publication 6 Aug. 1992. Accepted for publication 21 May 1993. Massachusetts Agricultural Experiment Station paper no. 3074. This research was supported in part by experiment station project no.517 and grant no. VS- 1525-88 from BARD, the United States-Israel Binational Agricultural Research and Development Fund. The cost of publishing this paper was defrayed in part by the payment of page charges. Under postal regulations, this paper therefore must be hereby marked advertisement solely to indicate this fact more severely than those in white bags. The percentage of the surface that was red and scald development were positively correlated until 18 Sept., but negatively correlated after later harvests, a result suggesting that scald was related more to time of harvest than to red pigmentation. Albrigo and Childers (1970) found that the side of the fruit exposed to sunlight developed less scald than the shaded side.

When fruit are harvested on different dates and evaluated for scald development after storage, differences among fruit from different harvests probably are results of interacting factors. Trying to attribute these changes to specific conditions is difficult. We are attempting to predict scald development at harvest, and we need to know the relative importance of key preharvest conditions. Thus, the experiments reported here were designed to separate the effects of ripening, temperature, and light on the loss of scald susceptibility under the growing conditions of the northeastern United States.

\section{Materials and Methods}

Fruit. Apples for all experiments were harvested from mature trees at the Univ. of Massachusetts Horticulture Research Center, Belchertown, Mass. 'Cortland' and 'Gardiner Delicious' were used during three seasons, 1988 to 1990 ,

Low temperatures (hours <1OC) and sequential harvests. Two enclosed recording thermometers located in the orchard provided continual temperature records after 31 July, from which total hours below 10C to midnight before each harvest were counted. Apples were harvested three or four times each season at about weekly intervals to provide a range of hours below 10C before harvest. The total number accumulated in a season ranged from 21 to $187 \mathrm{~h}$ for 'Cortland' and from 62 to $365 \mathrm{~h}$ for 'Delicious'. Six replications were used for each cultivar, with one or two trees serving as a replication, depending on crop load.

Ripening. 'Cortland' apples were induced to ripen $\approx 1$ month prematurely by ethephon, so that they ripened before significant hours of low temperatures had accumulated. On 16 Aug. 1989, ethephon at 0 or $0.5 \mathrm{~g} \cdot \mathrm{liter}^{-1}$, and on $20 \mathrm{Aug}$. 1990, ethephon at 0, 0.25 or 0.5 g.liter ${ }^{-1}$ was applied to whole trees. In both years, it was applied once with a surfactant and sprayed to runoff. Five replications were used, each consisting of two trees for each ethephon 
rate. The apples were harvested twice each season: 6 and 13 Sept. 1989, and 1 and 6 Sept. 1990.

Light. Fruit were bagged to investigate the effects of light. Apples were covered with kraft paper bags in mid- to late August. Four or five replications were used; each replication included one tree with bagged fruit and one control tree of nonbagged fruit. The pairs were chosen randomly, except that in 1989, two replications were 'Redcort' and two were 'Cortland' (standard strain), and in 1990, all five replications were 'Cortland'. In 1989 and 1990, 250 and 200 apples per replication were bagged, respectively. Bags were pulled over one or more apples and tops were rolled shut and stapled. Apples were harvested twice each year: 18 Sept. and 2 Oct. 1989 and 1 and 9 Oct. 1990.

In 1991, thermocouples were placed near exposed apples and in bags with apples to determine if bagging caused any temperature differences. The average temperature inside the bags was $0.5 \mathrm{C}$ lower than the average temperature of the air surrounding the apples. Although small, the difference was statistically significant $(P \leq 0.001)$

Ripeness determination at harvest. Mean ripeness of 10 apples per replication of each treatment was determined on the day of harvest. Internal ethylene was measured using a gas chromatography (GC) (model GC-8A; Shimadzu Corp., Kyoto, Japan) with a 46-cm activated alumina column. The injector was at $110 \mathrm{C}$ and the column was at 40C. A gas sample was withdrawn from the core cavity with a 4-ml syringe and $1 \mathrm{ml}$ was injected into the GC. An integrator (model C-R3A Chromatopar; Shimadzu) was used to quantify ethylene. Starch was evaluated by dipping apples sliced at their equator into iodine solution and comparing pattern development to a standard chart: for 'Delicious', that of Priest and Lougheed (1988), and for 'Cortland', the 'Spartan.' chart of Lau (personal communication).

Scald evaluation. After 5 to 6 months at $0 \mathrm{C}$ in air, 25- to 150fruit samples from each replication from each harvest were evaluated for scald percentage and severity; the latter was judged with a score of 1 is $\geq 1 \leq 10 \%, 2$ is $\geq 11 \leq 33 \%, 3$ is $\geq 34 \leq 66 \%, 4$ is $\geq$ $67 \leq 100 \%$ of the surface area exhibiting scald. Mean scald scores are based only on fruit that developed scald.

Statistical analysis. Blocking was done where possible and, in experiments involving treatments, randomly selected trees (replications) were treated. Statistical analysis included analysis of variance and regression where appropriate. Regressions are reported as the nonreplication $r^{2}$ and are the percentage of nonreplication sums of squares with the linear or quadratic portions or both of the model, SAS statistical software (SAS Institute, Cary, N. C.) was used to analyze the data.

\section{Results}

Low temperature. In 1988, 'Cortland' apples were harvested over 3 weeks, during which hours below 10C increased from 73 to 187, the starch index (indicating starch hydrolysis) increased four-fold, and the internal ethylene concentration increased linearly (Table 1). At the fourth harvest, apples were in the climactericrise $\left(\log \mathrm{C}_{2} \mathrm{H}_{4}>0\right.$ ). At the first harvest in 1989,62 h below $10 \mathrm{C}$ had accumulated. Between the first and second harvest, no additional hours below 10C were recorded, but starch hydrolysis had advanced. Between the second and third harvests, an additional 90 $\mathrm{h}$ below 10C had been recorded, starch hydrolysis had advanced, and the climacteric had been initiated. In 1990, harvests spanned from 21 to $150 \mathrm{~h}$ below $10 \mathrm{C}$. The starch indexes increased more than five-fold over this period, and apples from the last two harvests were in the climacteric.

In 1988, 'Delicious' were harvested after 160 to $365 \mathrm{~h}$ below 10C had been recorded, but little ripening had occurred (Table 2). In 1989, they were harvested after 125 and $170 \mathrm{~h}$ below $10 \mathrm{C}$ and were in the climacteric at the second harvest. In 1990, hours below 10C increased from 62 to 150 between the first and last harvest, starch hydrolysis had occurred progressively, and fruit were in the climacteric at the last harvest.

Table 1. Harvest date, preharvest hours below 10C, and ripeness at harvest in relation to scald development on 'Cortland' apples after 4 to 5 months of storage at $0 \mathrm{C}$. Regressions with scald are the percentage of nonreplication sums of squares with the linear or quadratic portions or both of the model.

\begin{tabular}{|c|c|c|c|c|c|c|}
\hline Year & $\begin{array}{l}\text { Harvest } \\
\text { date }\end{array}$ & $\begin{array}{l}\text { Hours } \\
<10 \mathrm{C}\end{array}$ & $\begin{array}{l}\text { Starch } \\
\text { index }^{2}\end{array}$ & $\begin{array}{l}\mathrm{C}_{2} \mathrm{H}_{4} \text { concn } \\
\text { (log ppm) }\end{array}$ & $\begin{array}{l}\text { Scald } \\
(\%)\end{array}$ & $\begin{array}{l}\text { Scald } \\
\text { score }^{y}\end{array}$ \\
\hline \multirow[t]{4}{*}{$\overline{1988}$} & 15 Sept. & 73 & 1.2 & -1.13 & 71 & $1 . \overline{8}$ \\
\hline & 22 Sept. & 102 & 2.0 & -1.00 & 36 & 1.2 \\
\hline & 29 Sept. & 134 & 4.0 & -0.65 & 11 & 1.6 \\
\hline & 6 Oct. & 187 & 5.0 & 0.15 & 4 & 1.3 \\
\hline \multirow{2}{*}{$\begin{array}{l}\text { Regression with } \\
\text { percentage scald }(23 \mathrm{df})\end{array}$} & $\mathrm{L}^{* * *} \mathrm{Q}^{* * *}$ & $\mathrm{~L}^{* * *} \mathrm{Q}^{* * * *}$ & $\mathrm{~L}^{*}$ & & & \\
\hline & $93 \%$ & $85 \%$ & $49 \%$ & & & \\
\hline \multirow[t]{3}{*}{1989} & 15 Sept. & 62 & 1.0 & -1.06 & 99 & 2.9 \\
\hline & 22 Sept. & 62 & 1.7 & -0.86 & 99 & 2.7 \\
\hline & 4 Oct. & 152 & 4.7 & 0.08 & 29 & 1.3 \\
\hline \multirow{2}{*}{$\begin{array}{l}\text { Regression with } \\
\text { percentage scald (17 df) }\end{array}$} & $\mathrm{L}^{* * *}$ & $\mathrm{~L}^{* * *}$ & $\mathbf{L}^{* *}$ & & & \\
\hline & $98 \%$ & $85 \%$ & $58 \%$ & & & \\
\hline \multirow[t]{4}{*}{1990} & 17 Sept. & 21 & 1.3 & -0.97 & 98 & 2.7 \\
\hline & 24 Sept. & 79 & 1.5 & -1.19 & 78 & 1.9 \\
\hline & 3 Oct. & 127 & 4.3 & 0.23 & 46 & 1.6 \\
\hline & 11 Oct. & 150 & 6.8 & 2.08 & 49 & 1.6 \\
\hline \multirow{2}{*}{$\begin{array}{l}\text { Regression with } \\
\text { percentage scald ( } 23 \mathrm{df})\end{array}$} & $\mathrm{L}^{* * *}$ & $\mathrm{~L}^{* * *} \mathrm{Q}^{* *}$ & $\mathrm{~L}^{* * *}$ & & & \\
\hline & $82 \%$ & $78 \%$ & $53 \%$ & & & \\
\hline
\end{tabular}

Index: 1 to $3=$ immature; 4 to $6=$ mature; 7 to $9=$ overmature.

'Score reflects percentage of surface affected of fruit that showed scald: 1 is $\geq 1 \leq 10 \% ; 2$ is $\geq 11 \leq 33 \% ; 3$ is $\geq 34 \leq 66 \% ; 4$ is $\geq$ $67 \leq 100 \%$.

${ }^{*, * * * * * *}$ Significant at $P \leq 0.05,0.01$, or 0.001 , respectively; $\mathrm{L}=$ linear, $\mathrm{Q}=$ quadratic. 
Table 2. Harvest date, preharvest hours below 10C, and ripeness at harvest in relation to scald development on 'Delicious' apples after 4 to 5 months of storage at 0C. Regressions with scald are the percentage of nonreplication sums of squares with the linear or quadratic portions or both of the model.

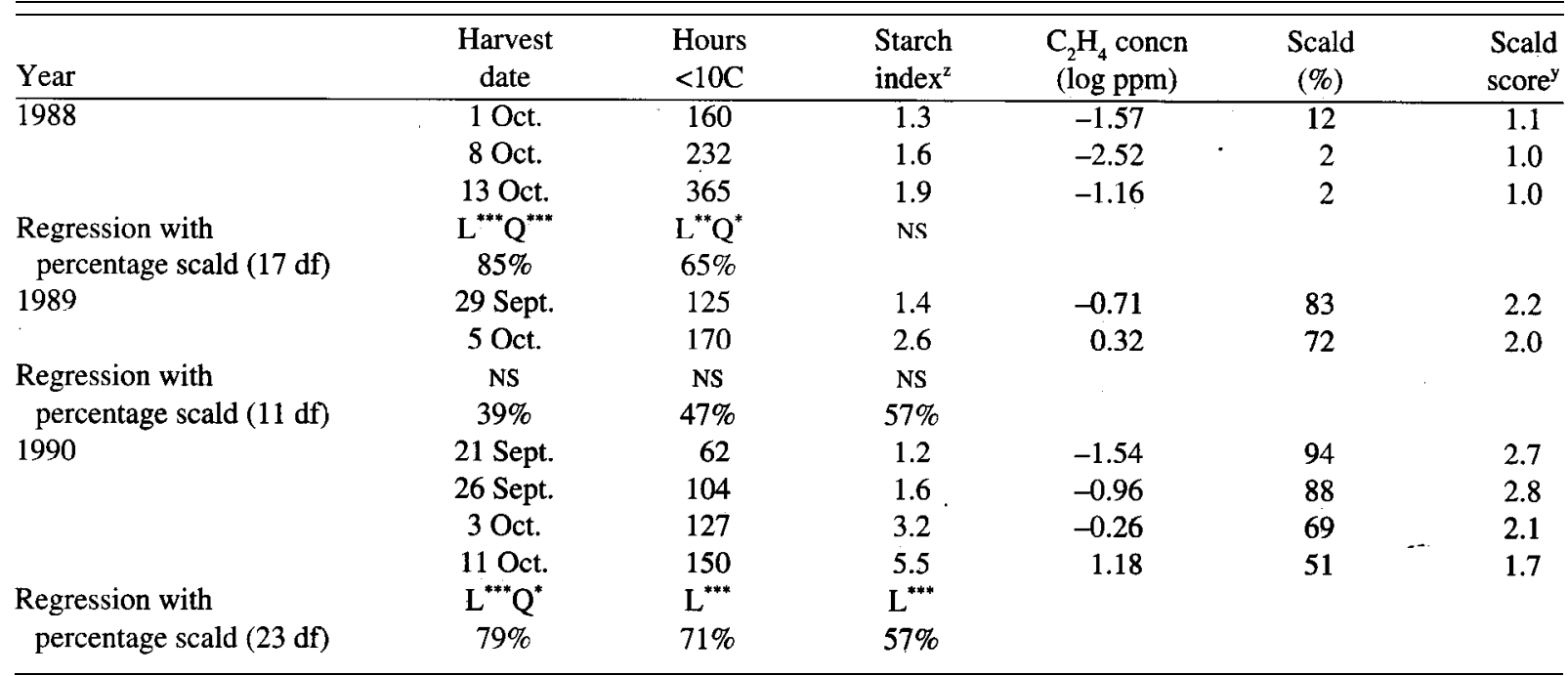

Index: 1 to $3=$ immature; 4 to $6=$ mature; 7 to $9=$ overmature.

'score reflects percentage of surface affected of fruit that showed scald: 1 is $\geq 1 \leq 10 \% ; 2$ is $\geq 11 \leq 33 \% ; 3$ is $\geq 34 \leq 66 \%$; 4 is $\geq$ $67 \leq 100 \%$.

Ns, $* * *, * * *$ Nonsignificant or significant at $P \leq 0.05,0.01$, or 0.001 , respectively; $\mathrm{L}=$ linear, $\mathrm{Q}=$ quadratic.

Scald incidence and severity after storage decreased with later harvest in most cases (Tables 1 and 2). For 'Cortland', scald reduction highly correlated with hours below 10C, harvest date (days from 1 Jan.), starch score, and log ethylene, and for 'Delicious', with hours below 10C and harvest date (Table 3). For both cultivars, the highest correlation was with hours below 10C.

For 'Cortland', all harvest variables were highly correlated with each other (Table 3). For 'Delicious', harvest variables were not as closely correlated, and hours below 10C showed no consistent association with either starch score or ethylene production.

These results show that there was a clear, largely linear, negative relationship between increasing hours below $10 \mathrm{C}$ between harvest dates and scald development after storage. Ripening also occurred between harvests, and it, too, was related significantly to scald development, although relationships between ripening indexes and scald generally were not as strong as those between hours below 10C and scald.

Ripening independent of low temperature. In 1989, ethephon-treated 'Cortland' apples were harvested twice, with 52 and $62 \mathrm{~h}$ below 10C accumulated, respectively (Table 4). In 1990, the apples. also were harvested twice, but there were no hours below 10C at either harvest.

Ethephon significantly hastened ripening in both years, as expressed by the starch index and ethylene production (Table 4). In both seasons, only those apples that were treated with ethephon were in the climacteric rise at harvest $\left(\log \mathrm{C}_{3} \mathrm{H}_{4}>0\right)$. Since both control and ethephon-treated fruit were exposed to the same environmental conditions before harvest, differences between treated and control fruit would be expected to represent only the effects of differences in ripeness at harvest.

In 1989, when 52 and $62 \mathrm{~h}$ below 10C were recorded, ethephon treatment reduced scald incidence, but not scald intensity (score) on affected fruit (Table 4). However, a substantial difference existed only after the second harvest (96\% vs. 67\%). In 1990, when there were no hours below 10C at either harvest, there was a significant quadratic relationship $(P \leq 0.01)$ between percentage scald and ethephon treatment; however, the nonreplication $r^{2}$ was
Table 3. Correlation matrix for data shown in Tables 1 and 2, combining years.

\begin{tabular}{lcccc}
\hline Variable & $\begin{array}{c}\text { Scald } \\
(\%)\end{array}$ & $\begin{array}{c}\text { Hours } \\
<10 \mathrm{C}\end{array}$ & $\begin{array}{c}\text { Harvest } \\
\text { date }\end{array}$ & $\begin{array}{c}\text { Starch } \\
\text { score }\end{array}$ \\
\hline Scald (\%) & \multicolumn{2}{c}{ Cortland } & & \\
Hours <10C & $-0.87^{* * *}$ & 1.00 & --- & --- \\
Harvest date & $-0.71^{* * *}$ & $0.90^{* * *}$ & 1.00 & --- \\
Starch score & $-0.65^{* * *}$ & $0.85^{* * *}$ & $0.94^{* * *}$ & 1.00 \\
Log ethylene & $-0.33^{* * *}$ & $0.60^{* * *}$ & $0.79^{* * *}$ & $0.88^{* * *}$ \\
& & Delicious & & \\
Scald (\%) & 1.00 & --- & --- & --- \\
Hours <10C & $-0.78^{* * *}$ & 1.00 & --- & -- \\
Harvest date & $-0.75^{* * *}$ & $0.84^{* * *}$ & 1.00 & --- \\
Starch score & $0.02^{\text {Ns }}$ & $0.00^{\mathrm{Ns}}$ & $0.47^{* * *}$ & 1.00 \\
Log ethylene & $0.27^{*}$ & $-0.11^{\mathrm{Ns}}$ & $0.27^{*}$ & $0.77^{* * *}$ \\
\hline
\end{tabular}

Ns,*,**Nonsignificant or significant at $P \leq 0.05$ or 0.001 , respectively.

only $36 \%$, a result indicating a weak relationship, and the differences were very small. All samples developed at least $90 \%$ scald, and scald intensity was greater on affected ethephon-treated than on affected control fruit.

Light. Scald incidence increased significantly by bagging in both years (Table 5). In all but the first harvest in 1989, where almost all apples scalded, the bagged fruit had at least twice as much scald as the control fruit. Bagging also increased scald scores in 1989. Bagged fruit ripened at the same rate as nonbagged fruit, as measured by starch index or internal ethylene concentration.

\section{Discussion}

Under normal orchard conditions in the northeastern United States, changes in hours below 10C, ripening, and light intensity are confounded. Therefore, our sequential harvests (Tables 1 and 2) represented the combined effects of all three factors. Using statistical procedures to separate the relative contributions of the 
Table 4. Effects of ethephon on ripeness at harvest and scald development on 'Cortland' apples after storage at 0C. Ethephon was applied on 16 Aug. 1989 and 20 Aug. 1990.

\begin{tabular}{|c|c|c|c|c|c|c|c|}
\hline Year & $\begin{array}{c}\text { Harvest } \\
\text { date }\end{array}$ & $\begin{array}{l}\text { Hours } \\
<10 \mathrm{C}\end{array}$ & $\begin{array}{c}\text { Ethephon } \\
\text { (ppm) }\end{array}$ & $\begin{array}{l}\text { Starch } \\
\text { index }\end{array}$ & $\begin{array}{c}\mathrm{C}_{2} \mathrm{H}_{4} \\
(\log \mathrm{ppm})\end{array}$ & $\begin{array}{c}\text { Scald } \\
(\%)\end{array}$ & $\begin{array}{l}\text { Scald } \\
\text { score }^{y}\end{array}$ \\
\hline \multirow[t]{4}{*}{1989} & 6 Sept. & 52 & 0 & 1.2 & -1.05 & 87 & 2.2 \\
\hline & 6 Sept. & 52 & 500 & 7.4 & 2.0 & 81 & 2.8 \\
\hline & 13 Sept. & 62 & 0 & 1.3 & -0.64 & 96 & 2.5 \\
\hline & 13 Sept. & 62 & 500 & 8.4 & 2.13 & 67 & 2.0 \\
\hline \multirow[t]{6}{*}{1990} & 1 Sept. & 0 & 0 & 1.0 & -2.35 & 97 & 2.4 \\
\hline & 1 Sept. & 0 & 250 & 4.8 & 1.86 & 90 & 2.8 \\
\hline & 1 Sept. & 0 & 500 & 5.9 & 2.08 & 92 & 2.8 \\
\hline & 6 Sept. & 0 & 0 & 1.3 & -1.82 & 99 & 2.4 \\
\hline & 6 Sept. & 0 & 250 & 7.3 & 2.12 & 91 & 3.2 \\
\hline & 6 Sept. & 0 & 500 & 6.9 & 1.95 & 96 & 3.2 \\
\hline \multicolumn{8}{|c|}{ Significance } \\
\hline \multirow[t]{2}{*}{1989} & Ethephon & & & $* * *$ & $* * *$ & $* *$ & NS \\
\hline & Hours $<10 \mathrm{C}$ & & & NS & NS & NS & NS \\
\hline 1990 & Ethephon & & & $* * *$ & $* * *$ & $* *$ & $* * *$ \\
\hline
\end{tabular}

${ }^{\mathrm{z}}$ Index: 1 to $3=$ immature; 4 to $6=$ mature; 7 to $9=$ overmature.

${ }^{y}$ Score reflects percentage of surface affected of fruit that showed scald: 1 is $\geq 1 \leq 10 \%$; 2 is $\geq 11 \leq 33 \%$; 3 is $\geq 34 \leq 66 \%$; 4 is $\geq$ $67 \leq 100 \%$.

Ns,**,**** Nonsignificant or significant at $P \leq 0.01$ or 0.001 , respectively, by analysis of variance.

Table 5. Effects of bagging on ripeness at harvest and scald development on 'Cortland' apples after 4 to 5 months of storage at OC. Fruit were bagged 21 to 25 Aug. 1989 and 13 and 14 Aug. 1990.

\begin{tabular}{|c|c|c|c|c|c|c|c|}
\hline Year & $\begin{array}{c}\text { Harvest } \\
\text { date }\end{array}$ & Treatment & $\begin{array}{l}\text { Hours } \\
<10 \mathrm{C}\end{array}$ & $\begin{array}{l}\text { Starch } \\
\text { index }\end{array}$ & $\begin{array}{c}\mathrm{C}_{2} \mathrm{H}_{4} \\
(\log \mathrm{ppm})\end{array}$ & $\begin{array}{c}\text { Scald } \\
(\%)\end{array}$ & $\begin{array}{l}\text { Scald } \\
\text { score }^{y}\end{array}$ \\
\hline \multirow[t]{4}{*}{$\overline{1989}$} & 18 Sept. & Control & 62 & 1.3 & -1.18 & 95 & 2.6 \\
\hline & & Bagged & 62 & 1.6 & -1.27 & 100 & 3.2 \\
\hline & 2 Oct. & Control & 147 & 5.1 & -0.21 & 27 & 1.4 \\
\hline & & Bagged & 147 & 4.4 & 0.02 & 90 & 2.1 \\
\hline \multirow[t]{4}{*}{1990} & 1 Oct. & Control & 107 & 3.2 & -0.07 & 31 & 1.4 \\
\hline & & Bagged & 107 & 3.4 & 0.24 & 62 & 1.4 \\
\hline & 9 Oct. & Control & 150 & 6.4 & 1.21 & 13 & 1.4 \\
\hline & & Bagged & 150 & 6.0 & 1.41 & 42 & 1.2 \\
\hline \multicolumn{8}{|c|}{ Significance } \\
\hline \multirow[t]{2}{*}{1989} & Bagging & & & NS & NS & $*$ & $* *$ \\
\hline & Hours $<10 \mathrm{C}$ & & & $* * *$ & NS & $* *$ & $*$ \\
\hline & Bagging $\times$ hours & & & $* *$ & NS & * & NS \\
\hline \multirow[t]{3}{*}{1990} & Bagging & & & NS & NS & $*$ & NS \\
\hline & Hours $<10 \mathrm{C}$ & & & $* * *$ & $* *$ & NS & NS \\
\hline & Bagging $\times$ hours & & & NS & NS & NS & NS \\
\hline
\end{tabular}

Index: 1 to $3=$ immature; 4 to $6=$ mature; 7 to $9=$ overmature.

y Score reflëcts percentage of surface affected of fruit that showed scald: 1 is $\geq 1 \leq 10 \% ; 2$ is $\geq 11 \leq 33 \% ; 3$ is $\geq 34 \leq 66 \% ; 4$ is $\geq$ $67 \leq 100 \%$.

Ns, ${ }^{*}, * * * * *$ Nonsignificant or significant at $P \leq 0.05,0.01$, or 0.001 , respectively, by analysis of variance.

effects of temperature and ripening on loss of scald susceptibility, a hierarchy of associations emerged (Table 3). Percentage scald was correlated more strongly with preharvest hours below 10C than with any ripening index, a result similar to that which Merritt et al. (1961) reported for 'Stayman' and Blanpied et al. (1991) reported for 'Starkrimson Delicious'. Among the ripening indexes, harvest date and log ethylene were decreasingly associated with scald development. The only inconsistency between cultivars was in the relationship between starch score and percentage scald, which was highly significant for 'Cortland' but nonsignificant for 'Delicious'.

This greater association of temperature than ripening with scald development is evident from the data in Tables 1 and 2 . In 'Cortland', in both 1988 and 1990, percentage scald after storage declined with later harvest, during which intervals little or no ripening occurred (as indicated by ethylene production and starch hydrolysis), but hours below 10C rapidly accumulated. In 1989, no loss of scald susceptibility occurred when harvest was delayed from 15 to 22 Sept., during which all recorded hours were above 10C. In 'Delicious' there was almost no scald in 1988, even though fruit were still preclimacteric at all harvests, apparently due to a large accumulation of hours below 10C (Table 2). Conversely, in 1990, hours below 10C gradually accumulated overtime and scald susceptibility gradually declined.

According to regression of percentage scald on preharvest hours below 10C across years (Fig. 1), for 'Cortland', $60 \mathrm{~h}$ below $10 \mathrm{C}$ were required before scald incidence began to fall, but between 60 and $150 \mathrm{~h}$, scald development fell from $100 \%$ to $20 \%$. 
For 'Delicious', $100 \mathrm{~h}$ below 10C were required before scald incidence began to decline, but when 150 or more h below $10 \mathrm{C}$ had been recorded, $<20 \%$ of the fruit developed scald, These results are similar to those from our earlier studies (Bramlage and Barden, 1989) and illustrate a consistent relationship among years between preharvest temperature and scald susceptibility under our growing conditions.

The ethephon treatments directly tested the effects of ripening on scald susceptibility, since ripening was induced to occur with little or no exposure to $10 \mathrm{C}$ or lower. After the second harvest in 1989, when 62 h below 10C had occurred, ethephon-treated fruit developed substantially less scald than controls (Table 4), a result indicating that ripening reduced scald susceptibility. In 1990, however, when equivalent ripening occurred in the absence of any hours below 10C, at least $90 \%$ of the fruit in all treatments developed scald. Thus, induced ripening per se apparently contributed little to the loss of scald susceptibility, but when combined with a marginally effective amount of low temperature (Fig. 1) in 1989, ripening enhanced loss of scald susceptibility. Perhaps the greatest or most rapid effect of ripening on scald susceptibility requires an interaction with preharvest hours below 10C.

Enclosing fruit in paper bags did not significantly influence either temperature or ripening. Therefore, differences between bagged and control fruit should have been primarily the result of decreased light intensity, Those fruit that had been bagged developed significantly more scald in both seasons, and affected fruit also had greater scald intensity in 1989 (Table 5). Thus, light, as ripening, was probably a secondary or modifying factor in loss of scald susceptibility, with susceptibility persisting longer under low light intensity, as implied in earlier studies (Albrigo and Childers, 1970).

It may be argued that loss of scald susceptibility results from integrated effects of environment during fruit development over time and can be predicted from harvest date. Although harvest date was highly correlated with scald (Table 3), quite different amounts of scald occurred on fruit from corresponding harvest dates in different years. For example, 'Cortland' harvested on 22 or 24 Sept. produced 99\% (1989), 78\% (1990), and 36\% (1988) scald among years (Table 1), and 'Delicious' harvested on 1 to 5 Oct. produced 72\% (1989), 69\% (1990), and 12\% (1988) scald among years (Table 2). Similar poor relationships between percentage scald and harvest date were recorded for 'Granny Smith' apples in New Zealand (unpublished data). The high correlations between scald and harvest date probably only reflect the rapid changes in all attributes that occur during the short periods of time when apples are maturing and ripening. Attempts to predict scald development from harvest date likely would be disappointing due to different temperature patterns among years.

We conclude that low temperature was most responsible for rapid, substantial loss of scald susceptibility, and that light and ripening were secondary factors in this loss, interacting with the effects of temperature.

\section{Literature Cited}

Albrigo, L.G. and N.F. Childers. 1970. Peel flavanols and their relationship to superficial scald in 'Stayman' apples. J. Amer. Soc. Hort. Sci. 95:798-800.

Blanpied, G. D., W.J. Bramlage, C.L. Chu, M. Ingle, M.M. Kushad, O.L. Lau, and P.D. Lidster. 1991. A survey of the relationships among accumulated orchard hours below 10C, fruit maturity, and the incidences of storage scald on 'Starkrimson Delicious' apples. Can. J. Plant Sci. $71: 605-608$.

Bramlage, W.J. and C.L. Barden. 1989. Predictability of scald susceptibil-

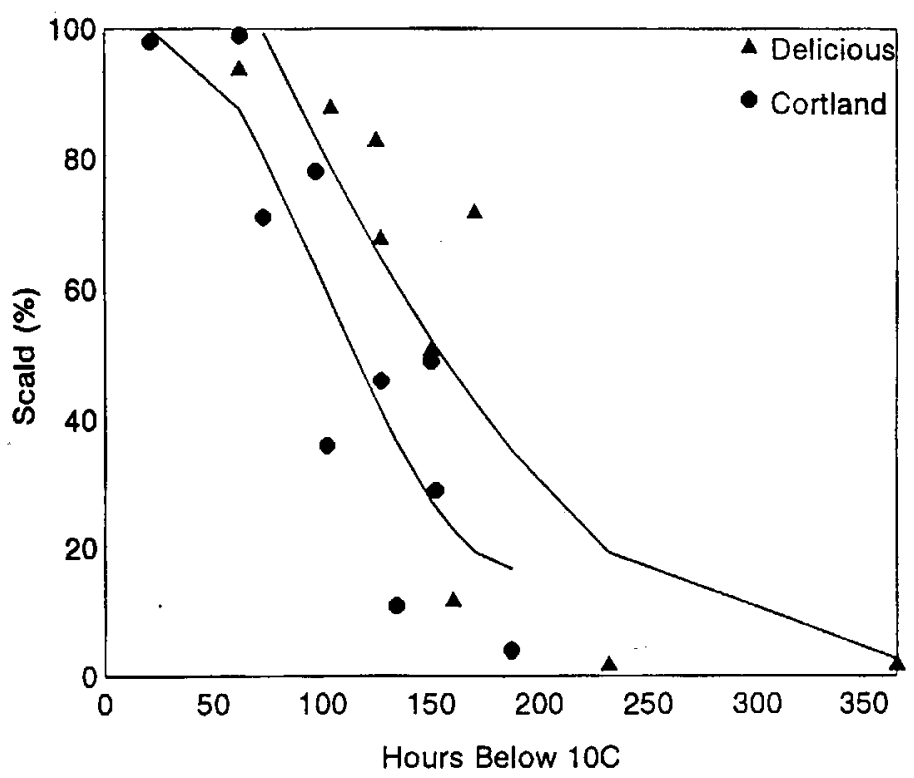

Fig. 1. Regression of scald development with preharvest hours below 10C for 'Cortland' (Scald $\left.=102+0.26 \mathrm{~h}-0.01 \mathrm{~h}^{2}+0.000033 \mathrm{~h}^{3}, \mathrm{r}^{2}=0.76\right)$ and 'Delicious' $\left(\right.$ Scald $\left.=158.3-0.901 \mathrm{~h}+0.0013 \mathrm{~h}^{2}, r^{2}=0.69\right)$ apples during 1988 to 1990 , Each point is the mean of six replications.

ity of apples. Proc. 5th Intl. Controlled Atmosphere Res. Conf. 1:137143.

Edgerton, L.J. and G.D. Blanpied. 1970. Interaction of succinic acid 2, 2-dimethyl hydrazide, 2-chlorethylphosphonic acid, and auxins on maturity, quality, and abscission of apples. J. Amer. Soc. Hort. Sci. 95:664-666.

Fidler, J.C. 1957. Scald and weather. Food Sci. Abstr. 28:545-554.

Greene, D. W., W.J. Bramlage, and W. J. Lord. 1977. Mid-summer applications of ethephon and daminozide on apples II. Effects on 'Delicious'. J. Amer. Soc. Hort. Sci. 102:494-497.

Greene, D. W., W,J. Lord, W.J. Bramlage, and F.W. Southwick. 1974. Effects of ethephon concentrations on quality of 'McIntosh' apples. J. Amer. Soc. Hort. Sci. 99:239-242.

Hammett,L.K. 1976. Ethephon influence on storage quality of 'Starkrimson Delicious' and 'Golden Delicious' apples. HortScience 11:57-59.

Meigh, D.F. and A.A.E. Filmer. 1969. Natural skin coating of the apple and its influence on scald in storage. III. $\alpha$-Farnesene. J. Sci. Food. Agr. 20:139-143.

Merritt, R. H., W.C. Stiles, A.V. Havens, and L.A. Mitterling. 1961. Effects of preharvest air temperatures on storage scald of 'Stayman' apples. Proc. Amer. Soc. Hort. Sci. 78:24-34.

Morns, J.R. 1964. The relationship of preharvest air temperature and several maturity indices to storage scald of 'Stayman' and 'Rome Beauty' apples. PhD diss., Rutgers Univ., New Brunswick. (Diss. Abstr. 65-5505.)

Padfield, C.A.S. 1955. Factors affecting incidence of superficial scald in the 'Rome Beauty' apple and its coloured sport, 'Frimley Beauty'. N.Z. J. Sci. Tech. 37:312-3 17.

Priest, K.L. and E.C. Lougheed. 1988. Evaluating maturity of 'McIntosh' and 'Red Delicious' apples. Ontario (Canada) Ministry of Agr. and Food Factsheet AGDEX 211/50.

Shutak, V.G. and J.T. Kitchin. 1966. Effect of time of harvest and apple color on storage scald. Proc. Amer. Soc. Hort. Sci. 88:89-93.

Smock, R.M. 1961. Methods of scald control on the apple. Cornell Agr. Expt. Sta. Bul. 970.

Smock, R.M. and F.W. Southwick. 1945. Studies on storage scald of apples. Cornell Agr. Expt. Sta. Bul. 843.

Windus, N.D. and V.G. Shutak. 1977. Effects of ethephon, diphenylamine, and daminozide on the incidence of scald development on 'Cortland' apples. J. Amer. Soc. Hort. Sci. 102:715-718. 